\title{
Trabalhadores, política e a Revolução de 1930 em Ilhéus, Bahia.
}

\section{Philipe Murillo Santana de Carvalho*}

\begin{abstract}
Resumo: O objetivo deste artigo é analisar as disputas políticas antes e depois da Revolução de 1930, tendo por objeto de estudo as relações entre os trabalhadores, o associativismo operário e as lideranças partidárias em Ilhéus, Bahia. A passagem da Primeira para a Segunda República foi marcada por uma movimentação relevante das oligarquias ilheenses em torno dos embates eleitorais para presidente e das turbulências que levaram à tomada do poder pela Aliança Liberal. Tal dinâmica política repercutiu no modo com que os diferentes partidos e autoridades buscaram se inserir nos mundos dos trabalhadores da cidade, procurando apoio nos grêmios de artesãos, caixeiros, carroceiros, carregadores etc., bem como mediar a luta por direitos e melhores condições de vida. Nesse sentido, pretendemos explorar até que ponto o proletariado ilheense esteve inserido neste cenário de confrontos políticos intensos pelo controle da República brasileira.
\end{abstract}

Palavras-chaves: trabalhadores, política e Revolução de 1930.

Abstract: The main objective of this article is to analyze the politics disputes before and after of the 1930's Revolution, it have by object of study the relationship between the workers, the proletarians associations and parties leaders at Ilhéus, Bahia. The passage of the First to the Second Republic were marked by a politic movement of the ilheenses oligarchic around the electoral shock for president and the turbulences that take on the Aliança Liberal to the public power. This dynamic reverberated in the form that differents parties and the politics entry in the workers world, looking for sustentation from the carregadores, carroceiros, commercial workers, etc., as well as intermediated the struggles for social rights and the better way of life. So, we pretend explore how the ilheenses proletarians were inserts in this canary of intenses politics confrontation by the control of the Brazilian Republic.

Keywords: Workers, politics and the 1930's Revolution

Não havia completado dois meses do movimento, que foi chamado de Revolução de 1930 pelos seus vencedores, quando os primeiros acertos de conta começaram a ocorrer no sul da Bahia. Eusínio Lavigne havia sido colocado no cargo de prefeito municipal, e uma de suas primeiras medidas foi abrir um livro de

* Doutorando do Programa de Pós-graduação em História Social da Universidade Federal da Bahia. Professor de história do Instituto Federal da Bahia - campus Ilhéus. philipesantana@yahoo.com.br 
petições para que a população pudesse registrar suas solicitações, reclamações e sugestões. Isso também já acontecia no regime decaído. A diferença era que as missivas eram respondidas, em grande parte, pelo próprio Lavigne, o que sinalizava como a postura do governo revolucionário para suprimir as distâncias entre governantes e governados se processou em Ilhéus. E foi exatamente em uma das petições enviadas para o prefeito que pudemos identificar uma interessante disputa.

Em 6 de dezembro de 1930, Nelson Schaun enviou requerimento para solicitar o pagamento de $780 \$ 000$ (setecentos e oitenta mil réis) por ter ocupado o cargo de oficial do Conselho Municipal entre os meses de setembro e outubro daquele mesmo ano, quando por força de decreto do Governo Provisório foi o legislativo extinto. A resposta, de próprio punho, enviada por Eusínio Lavigne evidenciou a intenção do novo prefeito em enfrentar os que tinham participado da Primeira República. Para iniciar, trouxe as palavras do ministro Oswaldo Aranha que afirmava não ser necessário reconhecer "os chamados direitos adquiridos dos funcionários públicos de mais de dez anos de serviços e os aposentados". Lavigne aplicava esta orientação em face da "anarquia administrativa e legislativa que formara um ambiente propício à constituição de leis imorais [...] fruto dos interesses partidários e, até, exclusivamente pessoal”. Por isso, o número significativo de "lugares criados para a colocação de amigos amparados por aquelas leis indecentes", avaliou o prefeito em seu despacho. ${ }^{1}$

Depois de sua análise conjuntural, o prefeito partiu para a análise específica do caso.

Nestas condições, se a Revolução visou, como visa restaurar o império da justiça, justo não é que se chame direito adquirido o oriundo de um interesse incompatível com a finalidade de toda lei, que não deve ter caráter personalista, mas viver da adesão moral do povo. Ora, é o caso desta petição, uma ofensa ao suplicante, que podia estar alheio ao ato dito legal. Os cargos de oficial e contínuo de um Conselho Municipal, que só se resume uma, duas ou três vezes por ano, representaram, por sua inutilidade e desnecessidade, verdadeiras sinecuras com sacrifícios das rendas municipais. Refletindo melhor, em face dos intuitos da Revolução, nota que tais pagamentos não procedem. ${ }^{2}$

Eusínio Lavigne, que também era bacharel em Direito, lançou mão de seu arcabouço jurídico para proferir uma peça textual que tentava aniquilar qualquer possibilidade de Nelson Schaun obter algum vencimento dos poderes públicos ilheenses. É possível notar o uso dos argumentos da Aliança Liberal presentes no documento. Neles, a "Revolução de 1930" está colocada como instrumento de regeneração das práticas políticas existentes na Primeira República, considerada pelos ideólogos do Governo Vargas uma experiência republicana negativa. Nesse sentido, cabe ressaltar que a configuração do movimento de outubro de 1930 como processo revolucionário fez parte do esforço político e discursivo que exaltava as ações dos aliancistas que se levantaram contra a I República brasileira, conforme salienta Edgar de Decca. ${ }^{3}$ Isso tudo seria refinado nos anos vindouros,

1 Arquivo Público Municipal de Ilhéus João Mangabeira (APMIJM). Livro de petições da Prefeitura de Ilhéus, 6/12/1930: ff. 35v-36.

2 APMIJM. Livro de petições da Prefeitura de llhéus, 9/12/1930. f. 36.

3 DECCA, Edgar de S. O silêncio dos vencidos: memória, história e revolução. São Paulo: Brasiliense, 2004. Para o autor, a memória constituída pelos vitoriosos de outubro de 1930 sustentava a periodização da história do Brasil republicano em duas etapas, cujo divisor de águas teria sido a Revolução, que viera 
com a elaboração de uma cultura política que diagnosticava o pré-1930 como "um momento de verdadeira decomposição do país", conforme salienta Ângela de Castro Gomes. ${ }^{4}$

No entanto, havia um motivo bem claro para que Eusínio Lavigne escolhesse Nelson Schaun para a lição de moral dos vitoriosos de outubro de 1930. Sabemos disso quando percorremos com mais detalhes a trajetória destes dois indivíduos. Desde 1928, quando as principais forças políticas do sul da Bahia, em especial as de Ilhéus, arregimentaram-se em torno do pleito eleitoral para presidente, promoviam embates políticos frequentes, seja por meio dos jornais ou das organizações operárias que frequentavam. Por enquanto, podemos saber que Schaun era professor e intelectual reconhecido, e tinha também uma atuação muito intensa nos grêmios laborais ilheenses, inclusive ajudando a fundar alguns deles - A Sociedade União dos Carregadores de Ilhéus (1926) e a Sociedade União dos Padeiros de IIhéus (1929). Além disso, foi o presidente da diretoria da Associação dos Empregados no Comércio de Ilhéus durante o biênio 1928-1929 e frequentava livremente a União Protetora dos Artistas e Operários de Ilhéus. ${ }^{5}$

Nelson Schaun também tinha uma atuação político-partidária bastante ativa. Era filiado ao Partido Republicano da Bahia (PRB), cuja liderança local era exercida pelo coronel e senador Antonio Pessoa, que esteve na hegemonia política de Ilhéus entre 1912 e 1930. Era comum que o professor fizesse a aproximação de agremiações operárias com os intendentes e os parlamentares do PRB. Isso explica o fato de Schaun ocupar o cargo de oficial contínuo do Conselho Municipal de Ilhéus, cuja presidência era exercida quase sempre pelo senador Pessoa. Mais do que isso, além de defender a chapa Júlio Prestes e Vital Soares, ele esteve ao lado da legalidade até às vésperas do dia 24 de outubro de 1930.

A rivalidade entre Schaun e Lavigne acentuou-se nas eleições de 1930. Eusínio Lavigne estava organizando a oposição local desde 1928, ano em que fundou o Centro de Cultura Democrática juntamente com sua esposa, Odília Teixeira Lavigne, e os senhores Misael Tavares, Helvécio Marques e José de Araújo Góes. ${ }^{6}$ Veremos mais à frente que por meio desta entidade, houve os primeiros contatos entre a oposição liderada por Lavigne e a União Protetora, um importante grêmio operário frequentado por Nelson Schaun. Em 1929, foi fundado o Comitê "PróAliança Liberal" de Ilhéus sob sua presidência, conclamando o "povo", "altivo e independente eleitorado" para conhecer as ideias aliancistas. ${ }^{7}$

Após esta breve contextualização, começa a ficar mais claro porque Lavigne não perdeu tempo em utilizar Schaun para uma punição exemplarmente. Ambos eram inimigos históricos e, por vezes, concorriam com o mesmo objetivo, inclusive o de se aproximar dos grêmios proletários. Também é possível compreender as disputas acirradas entre "aliancistas" e "legalistas" pelo controle da política de Ilhéus no contexto da Revolução de 1930 no País. Perceber no mesmo cenário figuras políticas que, de algum modo, já enxergavam na classe trabalhadora um ator coletivo preponderante. Por isso mesmo, ambos buscavam cortejar, na medida do possível, as organizações operárias antes e depois do processo revolucionário,

para remediar os males da política nacional. Neste caso, Decca ainda destaca que a historiografia marxista dos anos 1950-60 teria consumido esta memória histórica, sem ponderar criticamente a produção desta memória política. P. 72-73.

4 GOMES, Ângela de C. A invenção do trabalhismo. Rio de Janeiro, RJ: Editora da FGV, 2006. p. 192.

5 Cf. SCHAUN, Maria. Nelson Schaun merece um livro... Ilhéus, BA: Editus, 2001.

6 Biblioteca Pública do Estado da BAHIA (BPEB). Diário da Tarde, 13/8/1928, p. 1.

7 BPEB. Diário da Tarde, 28/10/1929, p. 1. 
o que nos faz vislumbrar continuidades entre as Primeira e Segunda repúblicas, flexibilizando noções de ruptura histórica do movimento de 1930.

Portanto, o objetivo deste artigo é analisar de que modo trabalhadores, organizações operárias e partidos políticos estiveram ligados às lutas políticas travadas no sul da Bahia na passagem da Primeira para a Segunda República brasileira; de que modo as autoridades lidaram com as questões operárias e com as organizações de trabalhadores antes e depois de 1930 em Ilhéus. Ao fim, poderemos saber o que permaneceu e o que mudou na prática de figuras políticas, associações operárias e partidos nesse período de turbulências políticas em llhéus e no Brasil.

\section{O Centro de Cultura Democrática, o Comitê Pró- Aliança Liberal e organizações operárias: a oposição se organiza}

Em 12 de agosto de 1928 foi dado o primeiro passo pela oposição política para o pleito eleitoral de 1930 com a fundação do Centro de Cultura Democrática de Ilhéus (CCD). O evento reuniu figuras bastante conhecidas na cidade, entre eles advogados, fazendeiros, funcionários públicos e comerciantes, tais como José de Araújo Góes, Henrique Devoto, Leones Fonseca, Enoch Carteado e o casal Eusínio Lavigne e Odília Teixeira Lavigne. Foram estes os fundadores e os responsáveis pela elaboração dos estatutos da nova agremiação. ${ }^{8}$ Em comum, todos tinham a condição de adversários do Partido Republicano da Bahia e de seu principal líder, o coronel Antonio Pessoa, que há mais de 16 anos estava no poder municipal.

O regulamento da instituição só ficou pronto em 26 de maio de 1929, quando, reunidos em assembleia, aprovaram os estatutos. Junto com ele, também foi publicado um manifesto ao povo e à nação contendo as principais ideias e objetivos do Centro de Cultura Democrática de Ilhéus. Em suas linhas, destacavam que a organização seria "genuinamente popular, destinada a ensinar os direitos políticos dos cidadãos brasileiros e a criar no país um 'um instinto de reformas sociais', correspondentes à sua cultura". Seus membros eram chamados de legionários democratas, e teriam a "missão" de instruir, educar e trabalhar "a massa popular" para os "arautos da democracia". O manifesto foi concluído com um reforço das ideias e dos princípios que motivaram a fundação do CCD. 9

Brasileiros! O Centro de Cultura Democrática de Ilhéus inspira-se na Fé vigilante do vosso heroísmo, nos hinos que cantais a liberdade, no amor com que acolhei as raças! Não nos retardes o passo alheio desvalor! [sic] Unamo-nos, Brasileiros, para o engrandecimento da pátria, sob o mesmo quarte da instrução democrática ${ }^{10}$.

Os membros do Centro de Cultura acreditavam que o desenvolvimento nacional só seria possível com liberdade e democracia a serem cultivadas nos brasileiros. Também, a intenção de criar um "instinto de reformas sociais" nos permite dizer que havia crítica e insatisfação com os rumos que a República havia tomado e o desejo de efetuar mudanças no País. Nesse sentido, a agremiação parecia sin-

\footnotetext{
8 BPEB. Diário da Tarde, 13/8/1928, p. 1

9 BPEB. Diário da Tarde, 27/5/1929, p. 2.

10 BPEB. Diário da Tarde, 27/5/1929, p. 2.
} 
tonizada com valores muito semelhantes aos que mais tarde seriam veiculados pela Aliança Liberal. Por enquanto é possível dizer que no intervalo entre a reunião de fundação e a de proclamação dos estatutos, o CCD ganhou novos adeptos, tais como João Amado (advogado), Edgar Lyra (comerciante e membro da Filarmônica 3 de maio), Acrísio Bezerra (médico), Francisco Dórea (fazendeiro e comerciante) e Luiz Lavigne, a maior parte deles de oposição ao governo municipal."

Havia um dispositivo nos estatutos do Centro de Cultura de Ilhéus que nos interessa mais de perto. Trata-se do artigo 3, que se refere à exploração de estudos sobre os "direitos dos representantes das classes populares no governo da nação, em harmonia com as organizações econômicas dessas classes". Este item, somado à intenção de formar as "massas populares", é indícios de que os membros do novo grêmio viam nas classes trabalhadoras um ator coletivo relevante para as reformas sociais que pretendiam defender para o Brasil. Tal pretensão fica ainda mais evidente na afirmação de que dar acesso ao conhecimento da política e da liberdade faria a "catequese dos princípios democráticos e práticas referentes ao dever cívico, aos direitos políticos dos cidadãos e às organizações econômicas das classes populares". ${ }^{12}$

A preocupação em se aproximar das classes trabalhadoras apresentadas pelos estatutos estava em sintonia com o vigor do associativismo em Ilhéus do final da década de 1930. Vários eram os grêmios operários que foram se estabelecendo na cidade, a maior parte deles havia surgido tendo por características a solidariedade e a beneficência, ofertando amparo financeiro, auxílio saúde e proteção jurídica, tais como a Sociedade União Operária dos Estivadores, a Associação dos Empregados no Comércio de Ilhéus e a União Protetora dos Artistas e Operários de Ilhéus. Esta última era uma das que maior número de sócios reunia, contado com um prédio social, uma filarmônica e uma escola noturna. Não por acaso, foi a União Protetora uma das primeiras investidas dos membros do Centro de Cultura Democrática para divulgar seus objetivos e conquistar adeptos. Por sinal, a sessão solene em que foram lidos e aprovados os regulamentos gerais ocorreu na sede daquela entidade, cuja escolha foi justificada por J. Araújo Góes por ser a "grande instituição operária" da cidade. ${ }^{13}$

A relação entre o Centro de Cultura Democrática e o universo dos trabalhadores foi facilitada pela mobilização vivida pelo operariado de Ilhéus entre maio e junho de 1929. Naquela oportunidade, Felício de Araújo, Alfredo Muritiba e Nazario Araújo, sócios diretores da União Protetora, publicaram um convite estendido a "todos os operários desta terra" para uma grande sessão de assembleia geral na Praça 2 de julho, que se destinava a discutir "assuntos em defesa de interesses palpitantes para todo o operariado ilheense - sob o ponto de vista nacional de sua unificação imprescindível [...] à semelhança do que está fazendo nos grandes centros trabalhistas". ${ }^{14}$

Certamente aproveitando a oportunidade da sessão convocada pela União Protetora, os membros do Centro de Cultura Democrática não só acompanharam de perto a mobilização do operariado, como fizeram um discurso sobre a "divisão das classes trabalhistas". O tema foi apresentado por J. Araújo Góes, que tentou explicar a "luta entre o capital e o trabalho" a partir do lucro extraído pela empresa e o salário pretendido pelo trabalhador. Tratou ainda da divisão existente

1 BPEB. Diário da Tarde, 27/5/1929, p. 2.

2 BPEB. Diário da Tarde, 27/5/1929, p. 2.

3 BPEB. Diário da Tarde, 27/5/1929, p. 1.

14 BPEB. Diário da Tarde, 28/51929, p. 4 
entre as categorias, concluindo que apesar da "distinção entre as classes trabalhistas, o conhecimento do direito político as conduzirá fortalecidas, com o povo, defendidas pela solidariedade resultante da comunhão de interesses, à suprema política". ${ }^{15}$ Em suma, o orador defendia o fortalecimento do proletariado por meio do conhecimento de seus direitos, enfatizando o potencial da unidade da classe para obter suas demandas frente aos governos.

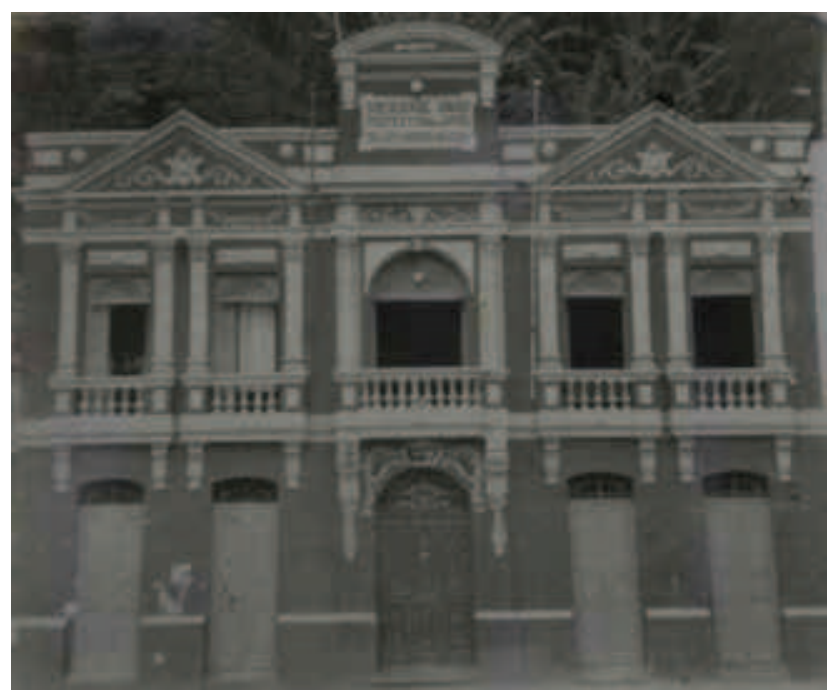

Figura 1- Sede da União Protetora dos Artistas e Operários de Ilhéus, onde se realizou a Assembleia Geral de apoio ao Centro de Cultura Democrática, 1930. Fonte: Acervo particular de Rute Almeida.

As palavras de Araújo Góes agradaram aos trabalhadores presentes na Assembleia Geral, haja vista que, ao fim da palestra, foi aprovada a proposta do vice-presidente da União Protetora José Ernesto da Silva de reconhecer a "alta finalidade do 'Centro de Cultura Democrática' e recomendar que seus associados aceitem a instrução que ele se propõe a dar gratuitamente ao povo". As simpatias dos artistas e operários de Ilhéus ao programa ideológico do CCD devem ter representado uma importante vitória para os oposicionistas do governo.

Convém salientar que a União Protetora era um grêmio operário frequentado por deputados, intendentes e coronéis da política situacionista há vários anos. Um dos mais conhecidos frequentadores era o deputado federal Ramiro Berbert de Castro (PRB), que garantia subvenções públicas desde 1925, comprava instrumental para a filarmônicae auxiliou na construção da Caixa Escolar que mantinha a escola noturna da entidade. Além disso, também a frequentava Nelson Schaun, que, como vimos, pertencia às fileiras do partido de situação em Ilhéus. Em vista destas ligações políticas, a porta aberta por Araújo Góes na Protetora significava um ato importante para um grupo que iniciava a caminhada na oposição para as eleições do ano seguinte (1930). Àquela altura, também as críticas contra o sistema eleitoral brasileiro chegavam às páginas da imprensa local, que destacava a idéia de que "em nosso regime [...] é de praxe o presidente escolher o seu sucessor, indicando o nome que deve ser eleito, nome que, de resto, é o nome sempre eleito" e que no "Brasil republicano o povo não tem a mínima influência nos seus próprios destinos". ${ }^{16}$

As atividades da Aliança Liberal em Ilhéus começaram em outubro de 1929. O comitê era formado por alguns dos sujeitos que faziam parte do Centro de Cultura 
Democrática, entre eles J. Araújo Góes, Francisco Dórea e Eusínio Lavigne, com a presidência sob a responsabilidade deste último. Foram publicados diversos editais na imprensa convidando a população para um comício a ser realizado no dia 27 de outubro de 1929 na sede da Associação Comercial de Ilhéus, onde seria constituído o grupo de apoiadores da chapa Getúlio Vargas - João Pessoa. ${ }^{17}$ No manifesto que foi publicado, os aliancistas ilheenses justificavam o apoio à candidatura de oposição como "uma atitude de reação contra o vezo de se deixar ao arbítrio do Presidente da República o critério da escolha do mais alto magistrado da Nação". A propaganda ainda buscava legitimar-se no amparo popular ao destacar que a candidatura de oposição vinha da "intervenção do povo nas lutas eleitorais" do País. ${ }^{18}$

O manifesto do comitê Pró-Aliança Liberal em Ilhéus também dava conta da participação de lideranças operárias entre seus integrantes. Da União Protetora, os apoiadores eram Felício Leão, artista que ocupou os cargos mais importantes do grêmio operário, entre eles o de presidente; Antonio Soares da Cunha Júnior, também presidente por vários biênios; e Alfredo Muritiba, tesoureiro e integrante da diretoria. Além deles, havia a presença de Pedro Ribeiro Filho, ferroviário com posições de destaque na organização da Caixa de Pensão e Aposentadorias da sua categoria; Abílio Guedes do Rosário, um dos diretores da Associação dos Empregados no Comércio de Ilhéus. ${ }^{19}$

A mobilização das forças de oposição de Ilhéus a partir do Centro de Cultura Democrática e da Aliança Liberal chamou a atenção dos membros do Partido Republicano da Bahia (PRB), que iniciou uma campanha de depreciação do programa político de seus adversários. Mas, antes disso, é importante destacar mais uma vez a presença de figuras políticas do PRB nas associações operárias da cidade.

\section{Oligarquias, trabalhadores e organizações proletárias no pré-1930}

Bem antes da organização dos grupos oposicionistas, os grêmios operários de Ilhéus construíram campanhas importantes no que tange à conquista de direitos. Entre 1925 e 1929, acompanhando a criação das leis sociais do final da Primeira República, operários, artistas, ferroviários, carroceiros e caixeiros engajaram-se na luta pela regulamentação da jornada de trabalho, pelo reconhecimento do direito de férias e na greve dos ferroviários da estrada Ilhéus-Conquista. Além disso, a dinâmica das associações proletárias era bastante intensa, com realização de comícios, de festejos e de promoção da educação popular. Na prática, elas possuíam um caráter mutualista e beneficente, cujos objetivos eram auxiliar os associados com proteção financeira, jurídica e médica no final da década de 1920 e 1930. Contudo, as sociedades também assumiam uma postura reivindicativa e espaço de pressão social por leis e benefícios para o proletariado junto ao Estado e aos patrões. ${ }^{20}$ Diante disso, as autoridades políticas colocaram tais associações no

BPEB. Diário da Tarde, 26/10/1929: p. 4.

18 BPEB. Diário da Tarde, 28/10/1929: p. 1 e 4.

19 BPEB. Diário da Tarde, 28/10/1929: p. 1 e 4.

20 Cf. BATALHA, Claudio H. M. "Formação da classe operária e projetos de identidade coletiva". In: FERREIRA, Jorge e NEVES, Lucília de Almeida Delgado. Brasil Republicano: o tempo do liberalismo excludente da proclamação da República à Revolução de 1930. Rio de Janeiro: Civilização Brasileira, 2010. Batalha esclarece que mesmo se constituindo como associações operárias mutualistas, elas também cumpriam por vezes funções de pressão social e de reivindicação de leis e de melhorias nas condições no início da República. 
roteiro de peregrinação nos momentos eleitorais, identificando o papel das suas representações frente às questões que reivindicavam.

Este era o caso dos deputados João Mangabeira e Ramiro Berbert de Castro. O primeiro era considerado o patrono das causas dos caixeiros, tendo inclusive interferido nas disputas internas que quase levaram ao fim da associação dos empregados no comércio em 1926. ${ }^{21}$ Aliás, era comum que às vésperas das eleições parlamentares Mangabeira retornasse a Ilhéus para angariar votos para si ou para seus candidatos. Em tais oportunidades, além dos discursos profícuos acerca da importância das classes trabalhadoras do sul da Bahia, Mangabeira prometia a manutenção das subvenções públicas, que eram verbas destinadas para a manutenção de escolas de alfabetização e/ou de formação técnica, ou ainda compra de instrumental para as filarmônicas.

Ramiro Berbert de Castro, igualmente, tinha bastante prestígio na União Protetora dos Artistas e Operários de Ilhéus, da qual também era sócio benemérito. Foi ele quem defendeu o projeto que tornou a entidade de "Utilidade Pública" no Congresso Nacional em $1925 .{ }^{22}$ Foi com este recurso, adicionado ao pagamento de mensalidades e de joias, que os artistas conseguiram construir a sede social da sua instituição, local onde também funcionava sua escola.

Porém, não apenas autoridades políticas cumpriam a tarefa de buscar a simpatia do mundo operário de Ilhéus. Esta atividade era dividida também com figuras como o professor Nelson Schaun, ao qual nos referimos no início deste artigo. Conforme dissemos, ele era um dos intelectuais mais prestigiados na cidade, ministrando aulas de português e de matemática no Ginásio Castro Alves e integrando o Grêmio Olavo Bilac, associação literária que reunia interessados em discutir poemas e romances de autores brasileiros. É bem provável que este ambiente acadêmico e intelectualizado tenha servido de espaço para projeção de jovens aspirantes ao reconhecimento social e aos postos de liderança operária. ${ }^{23} \mathrm{~A}$ nosso ver, Schaun soube aproveitar muito bem este cenário, inserindo-se nas principais sociedades literárias e operárias ilheenses. Além disso, sua notória desenvoltura com as letras abriu-lhe o caminho para atuar nos principais veículos de imprensa do sul da Bahia, entre eles, o Pequeno Jornal e o Correio de Ilhéus, sendo que este último era órgão oficial do Partido Republicano da Bahia e propriedade do coronel Antonio Pessoa.

$\mathrm{Na}$ imprensa local, Nelson Schaun publicou alguns textos tratando das conquistas de direitos dos trabalhadores no Brasil e no mundo. Escreveu sobre a necessidade da implantação da jornada de oito horas no comércio e nas indústrias, assim como registrou os debates realizados na União Protetora dos Artistas e dos Operários e grêmio dos caixeiros de Ilhéus no ano de 1926. Também esteve sintonizado com as leis sociais que foram regulamentadas ainda na Primeira República, em especial a Lei de Férias, que garantia o descanso anual dos trabalhadores urbanos por quinze dias, e a lei Eloy Chaves, de implantação das caixas de pensões e aposentadorias. No sul da Bahia, apesar da postura amistosa por parte das associações Comercial de Ilhéus e de Itabuna, as notícias eram de que vários patrões não obedeciam à recém-implantada legislação, forçando os grêmios operários a pressionarem os proprietários de casas comerciais através de ameaça de denúncias ao Conselho Nacional do Trabalho. ${ }^{24}$

21 Instituto Geográfico e Histórico da Bahia (IGHB). Pequeno Jornal, 13/3/1926, p. 1.

22 APMIJM. Correio de Ilhéus, 30/6/1925, p. 1

23 SCHIMIDT, Benito Bisso. Em busca da terra da promissão: a história de dois líderes socialistas. Porto Alegre: Palmarinca, 2004, p. 219.

24 IGHB. Pequeno Jornal, 30/11/1927, p. 1. 
Estas boas relações de Nelson Schaun com o universo operário possibilitaram que seu nome fosse cogitado para a candidatura a deputado estadual pelo PRB em 1926. Isso aconteceu na festa de aniversário do coronel Pessoa, quando um grupo de trabalhadores do distrito de Água Branca defendeu seu nome para o pleito eleitoral para a assembleia legislativa. A demonstração de apoio levou Schaun a agradecer a postura "altruística" do "movimento daquela falange de trabalhadores". ${ }^{25}$ No entanto, ao que tudo indica, a candidatura não chegou a ser oficializada pelo partido.

Entre as mobilizações nas quais Nelson Schaun participou, talvez a de maior projeção tenha sido a luta pela implantação da Semana Inglesa no comércio local ocorrida entre 1928 e 1929. Então, ele já havia se tornado o presidente da diretoria do grêmio dos caixeiros e tinha também contatos significativos com a União dos empregados no comércio do Rio de Janeiro e com Associação dos Empregados no Comércio da Bahia, que repassavam as informações dos grandes centros sobre os avanços nas leis sociais produzidas ainda Primeira República. Desse modo, liderou campanhas como a da regulamentação do horário de abertura do comércio. Utilizando-se da premissa de que Ilhéus deveria se moldar nas experiências das nações civilizadas, onde os trabalhadores conquistavam seus direitos em prol de melhores condições de vida, defendeu que o comércio operasse até sábado ao meio dia, conservando-se fechado aos domingos, dias santos e feriados nacionais. ${ }^{26}$

Com a resistência dos patrões à iniciativa, o caso da Semana Inglesa ganhou repercussão na associação Caixeiral e na imprensa. Liderados por Schaun, que no período era redator do jornal Correio de llhéus, de propriedade do coronel Antonio Pessoa, os caixeiros recorreram ao Conselho Municipal para criar uma lei que regulamentasse o funcionamento do comércio. Oportuno lembrar que, também neste período, Nelson Schaun ocupou o cargo de oficial contínuo no poder legislativo da cidade, que, por sinal, era presidido pelo mesmo coronel Pessoa, conforme dito na parte inicial deste trabalho. Com tamanha assessoria no conselho municipal, os edis aprovaram a criação da lei 353 que proibia a abertura das casas comerciais depois das 13 horas aos sábados e durante os domingos.

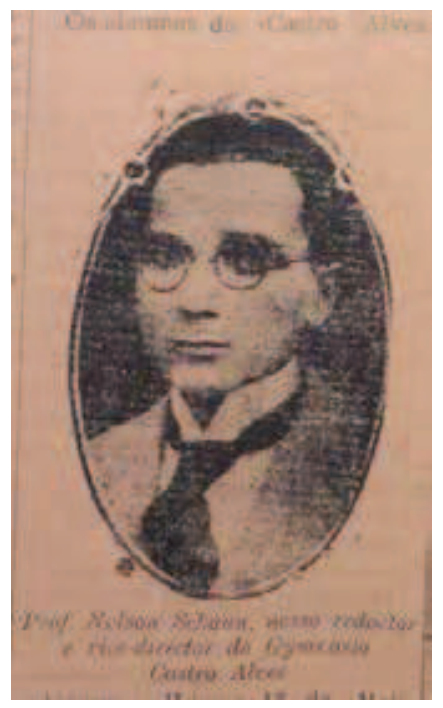

Figura 2 - Nelson Schaun, fotografia publicada no Correio de Ilhéus, 1929. Fonte: APMIJM. Correio de Ilhéus, 14/5/1929, p. 1

25 APMIJM. Correio de llhéus, 31/8/1926, p. 1.

26 APMIJM. Correio de llhéus, 18/2/1928, p. 2. 
Os caixeiros fizeram homenagens ao coronel Antonio Pessoa, colocando inclusive sua fotografia no interior da sede social. Por sua vez, o professor Schaun tornouse o presidente da diretoria da associação dos "moços do comércio" no biênio de 1929-1930, mostrando assim seu envolvimento com uma das categorias mais representativas de Ilhéus. ${ }^{27}$ Do mesmo modo, a referida sociedade reproduziu uma foto do recém-diretor, anotada pelo jornal do PRB como um "ato de reconhecimento dos caixeiros" que "teve um cunho altamente significativo, pois, no meio das lutas em que se empenha [...] em prol de reivindicações das classes trabalhadoras". ${ }^{28}$

Foi com este prestígio entre os operários e gozando de boas relações no interior das oligarquias ilheenses que Nelson Schaun chegou até o processo eleitoral de 1930. Antes disso, ele ainda auxiliou na fundação da Sociedade União dos Padeiros e dos grêmios dos carregadores. Sem dúvida, o professor era um dos correligionários do Partido Republicano da Bahia mais proeminentes entre os trabalhadores, apesar das tentativas de Eusínio Lavigne de desgastá-lo com os caixeiros quando do chamado "Caso Gromô". Este foi um episódio em que Everaldo Farias, uma das lideranças dos caixeiros, foi preso sob a acusação de envolvimento com furtos de produtos numa loja de tecidos em 1929. Na oportunidade, Lavigne acusou a associação dirigida por Schaun de omitir auxílio jurídico para a defesa do suspeito, que era tido por trabalhador honesto na cidade. ${ }^{29}$

\section{A hora dos comícios e das visitas}

As disputas eleitorais ficaram mais acirradas a partir de novembro de 1929. Comícios foram montados para debater as ideias dos "Liberais" e dos defensores da situação. Um deles ocorreu no dia 10 daquele mês, às 5 horas, em pleno centro da cidade, na Praça Luiz Viana, próximo ao Bar Avenida (atualmente conhecido por Vesúvio) e foi registrada pelos dois periódicos ligados aos grupos políticos envolvidos nas eleições. O Correio de Ilhéus informou que o comício teve a participação de "três defensores do falso liberalismo" e um dos "conservadores". Chamou atenção também para a fala de Schaun que, nas palavras do periódico, gozava:

[...] de grande prestígio no seio da população de sua terra, onde sua palavra está acostumada a ser ouvida na defesa dos melhores ideais, das causas mais justas [...] falou o professor Nelson Schaun, ouvido religiosamente, por quase uma hora, sobre a necessidade moral de se apoiarem aqueles que, de presente, se nos alevantam capazes de prosseguir no trabalho de bem fazer e de estabilizar o Brasil na ordem, na economia, na moralidade. ${ }^{30}$

Ao dizer que suas palavras estavam associadas à defesa das "causas mais justas", é bem provável que o professor procurasse recuperar na memória da assistência sua atuação entre as causas do operariado para legitimar sua defesa da chapa Julio Preste-Vital Soares. Outro comício foi realizado pelo Partido Republicano ilheense no dia 6 de dezembro de 1929, na mesma Praça Luiz Viana. Mais uma vez Nelson Schaun tomou a frente na defesa do governo, apontando os avanços sociais que teriam ocorridos tanto na gestão de Washington Luiz, quanto no

27 APMIJM. Correio de llhéus, 16/10/1928, p. 2.

28 APMIJM. Correio de llhéus, 22/1/1929. p. 1.

29 BPEB. Diário da Tarde, 22/2/1929, p. 1-2

30 APMIJM. Correio de llhéus, 12/11/1929, p. 1. 
comando local do coronel Antonio Pessoa. Embora o discurso não especifique que tipo de melhorias tenha ocorrido, não seria demais pensar que a fatura do apoio às reivindicações dos caixeiros e à greve dos ferroviários, por exemplos, tenha sido cobrada nas falas dos oradores.

Além dos comícios, os jornais cumpriram tradicionalmente o papel de propaganda eleitoral dos candidatos. No caso da situação, o Correio de Ilhéus passou a publicar reiteradas matérias para influenciar os votantes. Uma das medidas tomadas pelos correligionários de Schaun foi colocar na plataforma política da candidatura conservadora questões ligadas à regulamentação do trabalho, elemento considerado um dos "mais difíceis problemas morais e sociais do país". Destacou ainda os "esforços para que seja votado o Código do Trabalho, não só como obrigação de uma solidariedade humana para com todos aqueles que engradecem a Pátria, com o seu labor quotidiano, como também para cumprir a obrigação assumida no tratado de Versalhes". ${ }^{11}$

Tais considerações sobre a regulamentação do trabalho sinalizam que mesmo os defensores do partido situacionista reconheciam a demanda do operariado e sua força emergente num processo eleitoral tão disputado como o de 1930. Indício de que uma análise retrospectiva das disputas eleitorais desenhadas neste período indica a incorporação de benefícios legais antes mesmo da chegada de Vargas ao poder, como sinaliza Viscardi. ${ }^{32}$ Aliás, o próprio Nelson Schaun tinha sido um dos principais propagandistas dos avanços das leis sociais nas últimas gestões presidenciais da Primeira República, sobretudo da criação do Conselho Nacional do Trabalho, da lei de férias e da regulamentação da jornada de trabalho. No entanto, isso não significou que as autoridades políticas e o Estado estabelecessem relações harmoniosas com o coletivo dos trabalhadores, mas sim que o operariado emergia como um ator coletivo relevante no cenário político nacional, capaz de pressionar os poderosos para obter conquistas e para uma efetiva formulação e implementação de um legislação social mais sólida a partir de 1930, tal como se refere Castro Gomes. ${ }^{33}$ Dito de outro modo, podemos também afirmar com solidez que há muito de continuidade nas lutas e nas políticas dos trabalhadores em torno dos seus direitos na passagem da Primeira para a Segunda República.

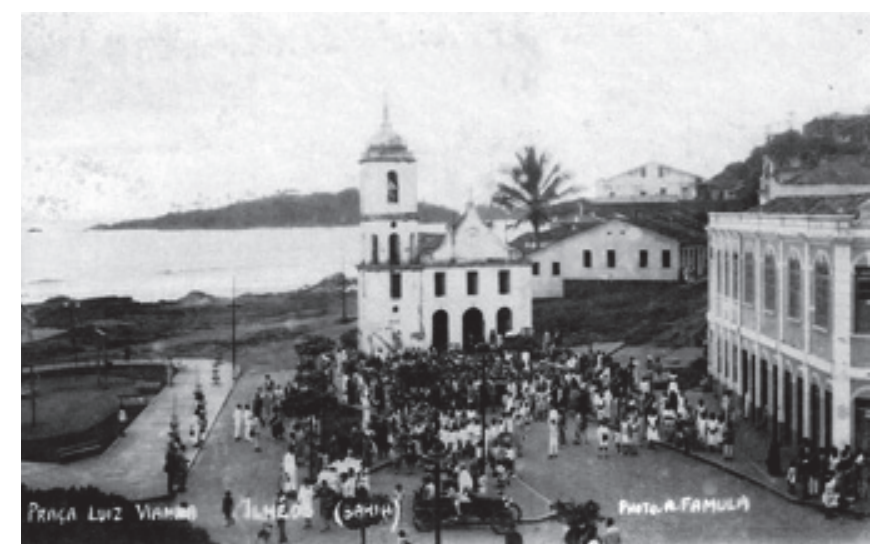

Figura 3 - Praça Luiz Viana, centro de Ilhéus. Neste local se realizava boa parte dos comícios políticos na década 1920. Fonte: SOUB, José Nazal Pacheco. Minha Ilhéus: fotografias do século XX. Itabuna: Via Litterarum, 2010.

31 APMIJM. Correio de llhéus. 23/1/1930, p. 1

32 VISCARDI, Claudia M. R. "Trabalho, previdência e associativismo: as leis sociais na Primeira República”. In: LOBO, Valéria M., DELGADO, Ignácio G., VISCARDI, Claudia M. R. (orgs.). Trabalho, proteção e direitos: o Brasil além da era Vargas. Juiz de Fora, MG: Editora da UFJF, 2010, pp. 29-61.

33 GOMES, Ângela de C. Cidadania e direitos do trabalho. Rio de Janeiro: Jorge Zahar Editor, 2002, pp. 18-20. 
Os ânimos dos eleitores estavam bastante acirrados às vésperas das eleições em Ilhéus. De acordo com a imprensa, "viu-se na praça até gente que nunca tomou parte em meetings, nem jamais se alistou em batalhão político". Era comum que os adversários comparecessem aos comícios realizados por ambos os partidos, fazendo com que as tensões ficassem mais fortes. Por isso, os defensores da chapa da situação solicitavam que seus correligionários não se fizessem presentes nos encontros da Aliança Liberal, evitando "questões que podem trazer consequências funestas, apesar da índole ordeira do nosso povo". ${ }^{34}$ Deste modo, em meio ao concorrido pleito presidencial de 1930, os trabalhadores e suas organizações viveram o clima de debate eleitoral entre aliancistas e conservadores, seja nos comícios ou no interior das associações. Exemplo disso é que deputados e coronéis passaram pelos grêmios proletários da cidade às vésperas das eleições para prometer subvenções federais aos operários e artistas, que em troca, conferiram diversas homenagens aos parlamentares.

No dia 19 de fevereiro de 1930, João Mangabeira pisou em Ilhéus ao som da filarmônica da União Protetora, onde fez discurso político, aos que lhe foram recepcionar, sobre os rumos da política brasileira, cujo tema central deve ter sido as eleições. Dias depois, o deputado federal compareceu à aplicação dos exames de datilografia da Escola Remignton, gerenciada pela $\mathrm{AECl}$. Ao final das provas, Nelson Schaun tomou a palavra para congratular-se "com os neo-diplomados e aproveitou o ensejo da presença de João Mangabeira, para em nome dos empregados no comércio de Ilhéus, render-lhe mais um preito de sincera gratidão, pelo muito que S. Exa. fez pela $\mathrm{AECl}$, o que lhe valeu com justiça, o título de benemérito". Mangabeira prometeu em sua resposta "ainda mais trabalhar" pelos caixeiros, "cuja eficiência e cujas nobres conquistas bem se percebiam através de mais esse atestado material, a que se assistia naquele momento". ${ }^{5}$ Apesar da retórica de seu discurso, não era em vão que o parlamentar presenciasse uma simples realização de avaliação na escola dos caixeiros. O clima eleitoral e a busca pelos votos certamente estiveram na ordem do dia daquela formatura. Por sua vez, Schaun cumpria mais uma vez o papel de "homem-ponte" entre os trabalhadores e as autoridades políticas da Primeira República.

Quem também desembarcou no porto de Ilhéus foi o deputado Ramiro Berbert de Castro. Ele chegou em 25 de fevereiro de 1930 e foi também recepcionado pela Filarmônica da União Protetora ao som da sinfonia O Guarany. No ritual de recepção para a autoridade, o professor Camilo Lellis da Matta e uma aluna do Colégio da União Protetora deram as boas-vindas e lideraram o cortejo que o deixou em seu palacete. Lá, o aguardavam as lideranças ilheenses do Partido Republicano da Bahia, entre eles João Mangabeira, coronel Antonio Pessoa, dr. Helvécio Marques e Nelson Schaun, que conforme já se tornara comum, fez o discurso de homenagem ao parlamentar. Ao se despedir do público que o havia acompanhado desde o porto, Berbert de Castro regozijou-se "pelas grandes vitórias, pelas conquistas morais, políticas e sociais que vem alcançando nestes derradeiros dias, em que se congraçam as forças todas positivas desta zona, notadamente o senador Antonio Pessoa e o deputado João Mangabeira, para a finalidade gloriosa e magnífica da hegemonia deste rincão abençoado". ${ }^{36}$

As palavras proferidas por Ramiro Berbert de Castro foram claras quanto ao objetivo da visita dos parlamentares a Ilhéus. A intenção era ir a campo para 
ganhar as concorridas eleições de 1930. Entenda-se por isso, disputar voto a voto com os adversários da Aliança Liberal, indo às escolas, associações proletárias, hospitais filantrópicos etc. Na União Protetora, o deputado entregou instrumentos musicais, importados da França, no valor de nove contos de réis para a banda da associação assim como uma caderneta de poupança e mil exemplares do seu livro Conferências. Passou ainda pela União dos Estivadores de Ilhéus e ofertou um conto de réis para os cofres da entidade. ${ }^{37}$

Enquanto isso, os aliancistas enfatizaram a missão de regenerar a política brasileira em suas propagandas eleitorais no Diário da Tarde. Eusínio Lavigne escreveu manifestos e cartas em que conclamava o povo "independente e livre" para sufragar a chapa Getúlio Vargas e João Pessoa, em nome "da honestidade, do trabalho e da ordem". Embora houvesse poucas referências à criação de direitos trabalhistas no programa da Aliança Liberal em Ilhéus, algumas questões importantes eram citadas, tais como a instituição do voto secreto e instrução popular, que alegavam tratar-se de medidas que combatiam um governo que "degrada o Brasil, equiparando-o a uma confraria de poucos senhores sobre milhões de escravos". ${ }^{38}$

Tal como em várias partes do país, a chapa Júlio Prestes e Vital Soares obteve a vitória nas urnas de Ilhéus. O boletim eleitoral publicado na imprensa situacionista informava que houve 5.001 votos para os vencedores, obtendo Getúlio Vargas o pífio resultado de 13 votos. De sua parte, o Diário da Tarde espalhou a notícia de que as eleições haviam sido burladas, relatando que algumas mesas eleitorais continham problemas. Independentemente do resultado das eleições, interessa é notar que obter o apoio e os votos dos trabalhadores e das organizações operárias esteve na pauta dos políticos de ambos os lados da disputa presidencial. As recepções, as visitas e as atuações no interior dos grêmios proletários sinalizavam que ao menos ganhar a simpatia do operariado era ponto crucial às vésperas de ir às urnas. Para o historiador Gustavo Falcon, as práticas políticas adotadas pelos coronéis e parlamentares relegavam a "população trabalhadora das fazendas à condição de massa de manobra no jogo político municipal". 39

Embora Falcon cite a categoria dos trabalhadores rurais ao tratar da exclusão e da manipulação das massas, parece válido retomar a experiência política da Primeira República para entender melhor as dinâmicas que operavam o clientelismo e o favoritismo no sul da Bahia. Se de fato havia manipulação, parece que esta saía bastante cara. Apenas para citar o caso de Ramiro Berbert de Castro, ao somarmos suas doações e despesas com as entidades operárias, veremos que o parlamentar gastou mais de quatorze contos de réis apenas nos dias finais das eleições. Além das questões financeiras, João Mangabeira precisou se deslocar do Rio de Janeiro para se fazer presente nas principais associações proletárias da cidade em busca de voto. Os membros da Aliança Liberal buscaram se aproximar de lideranças do operariado para fortalecer o projeto da oposição. Comportamento como estes sinalizam que o exercício da dominação política não se fazia sem barganha. Antes, tais políticos anteciparam algo que ficaria mais evidente com o trabalhismo de Vargas, qual seja, cortejar os grêmios operários para conseguir o apoio político eleitoral necessários em tempos de disputas.

É possível afirmar, então, que apesar das frágeis estruturas com que funcionavam, as associações proletárias de Ilhéus tornaram-se um cenário importante

37 APMIJM. Correio de llhéus, p. 1.

38 BPEB. Diário da tarde, 26/2/1930, p. 1.

39 FALCON, Gustavo. Os coronéis do cacau. Salvador, BA: Centro Editorial da UFBA/ lanamá, 1995, p. 117. 
para realização dos debates sobre a grande política em 1930. Por isso, cabe repensar o clientelismo não como um mecanismo de aprisionamento, de inércia e de falta de "consciência de classe", mas como uma prática da cultura política brasileira em que se filiar a determinada facção partidária representava participar, de algum modo, das eleições e dos destinos políticos. A questão é que para militantes como Abílio de Guedes Rosário, membro da AECl; Felício Leão, diretor da União Protetora; e Nelson Schaun, por exemplo, não havia contradição entre a defesa das causas operárias e o alinhamento com os partidos das oligarquias do município. Claro que ao afinar-se com as facções oligárquicas, as lideranças e grêmios de trabalhadores contraíam para si o peso do atrelamento com coronéis e parlamentares. Porém, se pensamos no pragmatismo da política brasileira do final da Primeira República, talvez isso não fosse uma questão incômoda entre os trabalhadores, sobretudo para uma zona geográfica em que a difusão das ideias socialistas e anarquistas eram praticamente inexistentes até o final da década de 1920.

Convém considerar ainda que a emergência da classe trabalhadora enquanto ator coletivo em Ilhéus ocorreu mediante a atuação de lideranças no debate e na luta por direitos e melhores condições de vida. Vimos que campanhas pela jornada de trabalho e pelas férias estiveram no contexto em que as associações operárias da cidade se organizavam e buscavam se fazer reconhecer pelas autoridades políticas e pelos patrões. Aliás, isso não era nenhuma novidade, pois várias eram as agremiações da capital da Bahia que possuíam essa característica ainda na Primeira República, a exemplo do Centro Operário da Bahia e da trajetória de Manuel Querino, estudadas respectivamente por Aldrin Castellucci e Maria das Graças Leal..$^{40}$ Assim, coronéis e figuras políticas foram percebendo a importância de usar uma estratégia mais sedutora para lidar com estes sujeitos. O que nos faz pensar que o jogo político da Primeira República estava próximo da definição das relações paternalistas tratadas por Thompson. Para o historiador inglês, ver os trabalhadores relacionando-se com as classes dominantes não significa que os "de baixo" aceitem o paternalismo conforme as pretensões dos poderosos. Nesse sentido, pode-se notar o cálculo que lideranças e associações operárias faziam na equação em que o objetivo era promover e fortalecer a sua cultura associativa..$^{41}$ Deste modo, podemos ver que coronelismo e clientelismo não podem ser considerados conceitos que trancafiam o movimento dos trabalhadores. Claro que tais elementos da política brasileira ofereciam os limites de atuação do operariado ilheense, ou do que era política e socialmente viável dentro da estrutura republicana até 1930, mas dentro desse traçado, abrir campos para barganhar suas demandas por direitos, cidadania e proteção social.

\section{Pós-revolução de 1930}

Desde início de outubro, notícias e boatos acerca da situação do País circularam intensamente nas ruas, praças e ambientes públicos. Dizia o Diário da Tarde que Ilhéus era "a cidade [que] sabe mais da revolução do que o resto do país". ${ }^{42}$ Após as primeiras tensões entre os políticos dos distintos estados, chegavam

40 Cf. CASTELLUCCI, Aldrin A. S. Trabalhadores, máquina política e eleições na Primeira República. Tese de Doutorado. PPGH/UFBA, 2008 e LEAL, Maria das G. A. Manuel Querino entre letras e lutas, Bahia: 1851-1923. São Paulo: Annablume, 2009.

41 THOMPSON, E. P. Costumes em comum: estudos sobre a cultura popular tradicional. São Paulo: Companhia das letras, 1998, pp. 77-78.

42 BPEB. Diário da tarde, 6/10/1930. p. 1. 
notícias por meio dos telégrafos ou através dos rádios existentes nas repartições públicas e privadas. A chuva de informações que se abatia sobre a cidade repercutiu no modo com que as associações e o Tiro de Guerra 500 se comportaram nas incertezas da política brasileira. Os defensores da legalidade alertavam que medidas seriam tomadas contra os "boateiros que se reúnem nos bares, restaurantes e esquinas de ruas, espalhando notícias falsas e derrotistas, para desassossego da família ilheense, os quais serão presos e os seus nomes enviados ao dr. Secretário de Polícia, para os devidos fins". 43

O tenente delegado Jubelino Alencar dizia que os boatos eram reproduzidos por indivíduos que desejavam disseminar informações tendenciosas com o objetivo de subverter a ordem política. Segundo ele, um dos objetivos era também "minar as classes operárias e os humildes trabalhadores, homens do povo, insinuando-lhes perversas atitudes e ainda outros, fingindo-se amigo dos atiradores ilheenses, aconselham a estes gestos de rebeldia às ordens superiores". ${ }^{4}$ A preocupação das autoridades policiais era que dois grupos específicos assimilassem os ideais dos revolucionários: o operariado, que, como vimos, tinha diversas organizações em Ilhéus; e o Tiro de Guerra 500. É muito provável que os alertas do delegado estivessem atrasados em relação à efervescência política daquele momento. Às vésperas do dia 24 de outubro, os legalistas tentaram formar batalhões patrióticos, convocando os reservistas do Tiro 500, mas já era tarde demais, pois os atiradores estavam sob o controle do tenente José Anselmo, que deu suporte para a tomada do poder em Ilhéus e Itabuna pelos membros da Aliança Liberal.

No dia 25 de outubro, Eusínio Lavigne e Guilherme de Andrade enviaram um telegrama ao major Reis Príncipe, chefe do governo provisório da Bahia informando terem assumido, respectivamente, os cargos de prefeito municipal e delegado. Iniciava-se ali um governo que duraria até o golpe do Estado Novo. ${ }^{45}$ No entanto, os primeiros meses de governo de Lavigne seriam marcados por uma forte instabilidade política e social, com denúncias por parte de adversários locais do regime decaído, suspeitas de companheiros do comitê da Aliança Liberal e tensas relações com as organizações operárias de Ilhéus. ${ }^{46}$ Interessa-nos para os fins deste trabalho este último quesito.

Uma das primeiras questões dos mundos do trabalho com a qual o governo revolucionário precisou lidar foi com o horário de funcionamento do comércio de Ilhéus. Apesar das várias campanhas realizadas ainda na década de 1920, a regulamentação da jornada de trabalho dos caixeiros ainda era um tema recorrente entre patrões e empregados naquela cidade. A associação dos comerciários realizou assembleia geral para tratar do desrespeito do patronato ao horário de abertura e de fechamento de suas portas. Na oportunidade, a proposta lançada pelo associado Chrysanto Góes foi de criar uma comissão composta por seis membros, para solicitar ao prefeito Eusínio Lavigne que fosse "mantido rigorosamente o horário do fechamento às 18 horas, estabelecido por lei da prefeitura". 47

43 APMIJM. Correio de llhéus, 14/10/1930. p. 1.

44 APMIJM. Correio de llhéus, 14/10/1930. p. 1.

45 Arquivo Público do Estado da Bahia (APEB). Telegrama de Eusínio Lavigne e Guilherme Andrade para o major Reis Príncipe. 25/10/1930. ff. 2. Fundo: Secretaria de governo, cx. 1852, doc. 2022, cx. 1851, doc. 2021.

46 Para entender melhor as divergências e as disputas entre os aliancistas de Ilhéus, cf. LAVIGE, José L. Eusínio Lavigne - paradigma de caráter e honradez. Ilhéus, Ba: 2009. LAVIGNE, Eusínio G. Meus 87 anos e outros ensaios. 1982.

47 Centro de Documentação e Memória Regional / Universidade Estadual de Santa Cruz (CEDOC/UESC). Diário da Tarde, 10/1/1931. p. 1. 


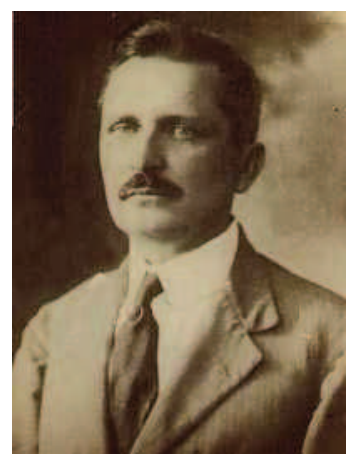

Figura 4 - Eusínio Lavigne, fundador da Aliança Liberal e prefeito de Ilhéus entre 1930 e 1937.

Os proprietários de casas comerciais enviaram também ao prefeito uma petição solicitando alteração do horário de funcionamento do comércio. De acordo com os patrões, a abertura deveria ocorrer às seis horas da manhã no período do verão, e as seis e meia durante o inverno, sendo que o encerramento das atividades ocorreria seis e meia da tarde no restante do ano. Os comerciantes pleiteavam ainda que em vésperas de feriados, o tempo se estendesse até às vinte horas. A justificativa para o pedido era que na capital federal e estadual os estabelecimentos mantinham-se em funcionamento das seis às dezenove horas, e que isto beneficiaria o povo com um maior tempo para resolver seus problemas. Em resposta, Eusínio Lavigne indeferiu alegando a falta de fundamento legal dos solicitantes, e que "os empregados no comércio precisam ou gozam, no exercício dos múltiplos e variados deveres, da cultura física, moral e intelectual, que a civilização moderna recomenda aos governos no interesse da eugenia social”. Àquela altura, os caixeiros já tinham realizado o encontro com o prefeito e encaminhado suas reivindicações, que parece terem sido atendidas. Conquanto, Lavigne consentiu que o comércio ficasse aberto até às sete e meia aos sábados, alegando que tal medida estava de acordo com a própria vontade dos empregados. ${ }^{48}$

As medidas tomadas por Lavigne quanto ao horário de funcionamento das casas comerciais resultou em boas relações com o grêmio dos "moços do comércio". Durante a posse da diretoria do biênio 1931-1932, os caixeiros convidaram o prefeito de Ilhéus para presidir a sessão solene e palestrar sobre a importância daquela associação. Em suas palavras, enalteceu "o valor dos núcleos e organizações de classe como aquela, dizendo que sua colaboração era indispensável na grande obra de desenvolvimento social". ${ }^{49}$ De algum modo, o discurso proferido sinalizava não apenas a intenção de estabelecer relações amistosas com a entidade, mas também de disseminar a ideia de que as organizações operárias deveriam colaborar com o governo. Isso já apontava para o projeto corporativo de incorporação da classe trabalhadora como base de apoio político e estabelecer os poderes públicos como mediadores das divergências nas relações de trabalho.

No caso de Eusínio Lavigne, apoio político e popular era algo que ele não podia dispensar em meados de 1931. As lideranças políticas do regime decaído, lideradas pelos integrantes da família do coronel Pessoa enviaram uma série de cartas acusando o prefeito de desmandos públicos e o delegado tenente José Anselmo de violência policial contra seus adversários. Havia ainda o "fogo-amigo" de aliados da revolução insatisfeitos com as medidas adotadas pela administração

48 APMIJM. Livro de petições da prefeitura municipal de Ilhéus, 19/1/1931. ff. 15V-16. Documento também reproduzido no CEDOC/UESC. Diário da Tarde, 21/1/1931. p. 4.

49 Diário da Tarde, 26/1/1931. p. 1. 
municipal. Em 23 de março de 1931, J. Araújo Góes distribuiu boletim intitulado “Ao povo - a nossa maior crise é de governo" em que exigia que a prefeitura suspendesse o pagamento das dívidas contraídas antes da mudança de governo e que os recursos fossem utilizados no crédito aos pequenos proprietários, no pagamento do funcionalismo municipal e na construção de obras públicas..$^{50}$

Em meio a tantas críticas, o prefeito de Ilhéus recebeu uma demonstração de solidariedade de algumas agremiações proletárias, entre elas, a Sociedade Beneficente dos Funcionários da Estrada de Ferro Ilhéus-Conquista. Os associados enviaram uma correspondência ao interventor Arthur Neiva afirmando "protestar contra a campanha infamante que elementos antiprogressistas movem contra Eusínio Lavigne, procurando assim perturbar a ação administrativa atual do prefeito que em boa hora dirige digna e operosamentes [sic] os destinos deste município". ${ }^{51}$ Infelizmente, ainda não temos fontes seguras para saber a natureza das relações entre Eusínio Lavigne e os ferroviários da cidade, mas vale recordar que Pedro Ribeiro Filho, um dos diretores da Caixa de Pensões e Aposentadorias da categoria, estava entre os membros da Aliança Liberal. Além disso, o que podemos notar é que se aproximar das organizações proletárias e contar com a solidariedade dos trabalhadores foi uma das práticas políticas assumidas pelo chefe do executivo.

A proximidade das comemorações do Dia do Trabalho ofereceu mais uma oportunidade para que o governo municipal pudesse dialogar com o operariado de Ilhéus em 1931. Liderados pela União Protetora, as sociedades de ferroviários, carroceiros e carregadores reuniram-se para celebrar de modo solene a data magna do $1^{\circ}$ de maio. A mesa dirigente das atividades realizadas foi composta por José Ernesto da Silva, diretor da sociedade promotora; presidida por Eusínio Lavigne e secretariada por Nelson Schaun. Curiosamente, estavam reunidos dois dos rivais mais ferrenhos nas disputas políticas de 1930 num cenário da cultura associativa operária ilheense. O encontro de Lavigne e de Schaun não parece ter intimidado o primeiro, pois proferiu discurso em que saudava os trabalhadores da cidade e enfatizava a importância das "classes laboriosas" estarem integradas na organização da sociedade, por ser um dos alicerces da nação. Dedicou palavras também para tecer "considerações oportunas sobre o ideal socialista que agita os povos conduzindo-os para uma fórmula de harmonia universal e redentora".52

Não sabemos efetivamente o que Eusínio Lavigne intencionou ao se referir ao "ideal socialista" como instrumento de harmonia e de redenção social, mas tudo leva a crer que o prefeito pretendia se apropriar dos debates políticos ideológico do operariado nacional para se aproximar dos interesses das associações. Esse trânsito no seio das agremiações de trabalhadores era um meio que Lavigne encontrava para angariar apoio e solidariedade, especialmente num contexto de instabilidade administrativa e política dos primeiros meses pós-revolução.

O primeiro semestre de 1931 foi também marcado por uma movimentação nos círculos dos trabalhadores de Ilhéus. Nesse período, algumas associações que tinham paralisado suas atividades retomaram a rotina de assembleias. Em paralelo, outras sociedades foram fundadas. Estes foram os casos, respectivamente, da Sociedade União dos Carregadores de Ilhéus, orgnizada ainda na década de 1920, suas atividades apareciam muito pouco na imprensa até 1931;53 da União dos Con-

50 APEB. Ao povo - nossa maior crise é de governo, 23/3/1931. f. 1. Fundo: Secretaria de governo, cx. 1852, doc. 2022.

51 CEDOC/UESC. Diário da Tarde, 26/2/1931. p. 1.

52 CEDOC/UESC. Diário da Tarde, 2/5/1931. p. 1.

53 CEDOC/UESC. Diário da Tarde, 6/2/1931. p. 1 
dutores de Carroça de Ilhéus; e da União dos Chaffeurs de Ilhéus. A agremiação dos carroceiros foi criada em ato solene no dia 29 de março de 1931 e visava reunir a categoria para regulamentar a atuação profissional e promover a defesa dos seus associados. O primeiro corpo de dirigente foi composto pelo presidente Arsenio Ribeiro Leitão, secretário Graciliano Rosendo dos Santos, tesoureiro Priamo José de Lemos e os delegados especiais Joaquim Lopes Filho e Nelson Schaun. ${ }^{44}$ No caso dos chaffeurs, desde início de fevereiro houve uma movimentação para organizar a categoria, resultando na fundação da sociedade no dia 8 de março, com sua administração composta por Edgar Guimarães, como presidente; Ananias Menezes no posto de $1^{\circ}$ secretário e Sílvio Berbert Amorim de $2^{\circ}$ secretário ${ }^{55}$.

O surgimento de novas entidades proletárias e a retomada das atividades que estavam inertes foram elogiadas pela imprensa ilheense, principalmente por parte do Diário da Tarde, que possuía ligações íntimas com o governo municipal. Em comentário, anotava:

\begin{abstract}
Vai-se acentuando, notavelmente, em nosso meio, o movimento associativo, de organização das classes, para a defesa e a assistência dos diferentes núcleos das atividades particulares. Assim tivemos outro dia a fundação da sociedade dos motoristas e agora a da união dos condutores de carroça, ambos os órgãos representativos das classes humildes do povo, mas nem por isso menos laboriosas e menos significativas no conceito social em toda parte. Vale aqui acentuar um dos objetivos principais dessa nova agremiação: fundar um colégio para os filhos dos seus associados e instruir um curso noturno [...] ora, não temos aqui ainda uma aula para os homens rudes que, entregues ao labor quotidiano, só a noite podem dedicar algumas horas de estudos. ${ }^{56}$
\end{abstract}

Como se percebe, a iniciativa de associação partia de uma parcela dos trabalhadores mais empobrecida, ora chamada de "humildes", ora de "rude" pelos redatores do periódico, praticamente ao mesmo tempo da lei de sindicalização regulamentada pelo Estado. Nesse sentido, as autoridades políticas certamente monitoravam essa dinâmica associativa com atenção, pois se tratava de categorias que promoviam sua organização independentemente dos poderes públicos e tornavam-se um ator coletivo de considerável potencial político e social. Adicionase a isso, o contexto de um governo municipal suscetível a instabilidades e desejoso de se aproximar do operariado ilheense.

Outra evidência da atenção dispensada ao movimento associativo dos trabalhadores pode ser notada na série de escritos de Eusínio Lavigne para propagandear a Legião de Outubro. No décimo artigo publicado, o prefeito analisou as reivindicações populares para que o governo provisório encaminhasse a constituinte do País, visando retomar o funcionamento do legislativo. Ele considerava que os chefes da República estavam preparando os suportes técnicos para integrar "o povo - por suas classes organizadas - sindicatos, associações, institutos" no projeto da nova constituição. ${ }^{57}$

A partir do mês de junho, as sociedades operárias de Ilhéus acentuaram sua mobilização. Além da União Protetora dos Artistas e Operários de Ilhéus ter renovado seu conselho de dirigentes, as agremiações dos carroceiros e dos carregadores também realizaram assembleias para tratar de questões trabalhistas no comércio e 
nas atividades portuárias da cidade. No dia 24 de junho, a União dos Carregadores informava às autoridades e à imprensa que reunira mais de 217 indivíduos para agregar à sua associação, os trabalhadores das docas e armazéns. Desse modo, o grêmio estaria organizado em dois setores: Seção de carregadores ambulantes, constituídas por aqueles que atuam nas ruas e que somavam 63 indivíduos; e a Seção de Trabalhadores das Docas e Armazéns, composta por aqueles que operavam nas dependências do porto, em número de 217 cidadãos. Por fim, o presidente Nelson Schaun destacou que a sociedade teria como objetivo "defender os direitos e interesses destas classes trabalhistas, prestando, além disso, assist". ${ }^{8}$

Os Condutores de Carroça realizaram assembleia dois dias antes da dos carregadores - dia 22 de junho - cuja deliberação resultou na publicação de um aviso regulamentando o exercício profissional da categoria. Diziam que em função da "saúde desses laboriosos e anônimos trabalhadores, que ao mesmo não competirão mais, a contar de $1^{\circ}$ de julho próximo, tomar ou entregar volumes dentro dos armazéns, tampouco subir escadas, como, desumanamente, vinha sucedendo". O que os carroceiros estavam exigindo era que as atividades de carga e descargas fossem cumpridas pelos trabalhadores das docas e dos armazéns. Nesse sentido, fica evidente que havia uma sincronia entre as sociedades dos condutores de carroça e dos carregadores para delimitar as funções de cada uma das categorias. Ademais, ambas as agremiações encontravam-se sob a direção de Nelson Schaun, sendo presidente dos carregadores e delegado especial dos carroceiros. Os donos de casas comerciais e as empresas de navegação obrigavam que o serviço de transporte e de carregamento dos produtos fosse realizado pelos carroceiros, e foi exatamente a esta condição que eles desejavam por fim em llhéus. Ao final, enfatizou que a "sociedade cumpre o dever de elucidar claramente, para evitar possíveis explorações que encara, na medida em apreciação, tão somente a defesa, a salvaguarda da saúde dos seus associados e que tudo fará dentro da ordem", acrescentando que observaria o "máximo respeito às leis e aos poderes constituídos, sem propósitos de violência ou subversões, esperando assim contar com o apoio necessário de todos, como felizmente conta com o apoio manifesto e valioso do Dr. Prefeito Municipal". 59

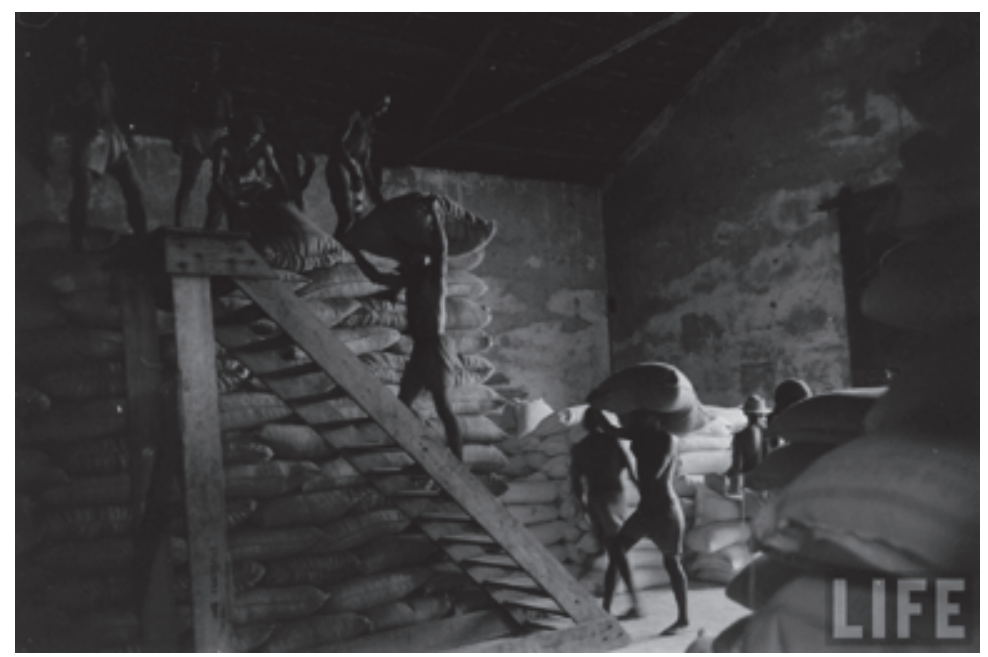

Figura 5 - Fotografia do trabalho de descarga das sacas nos armazéns do Porto de Ilhéus, década de 1950. Ainda nesse período é possível ver as extenuantes escadas enfrentadas pelos trabalhadores do porto. Fonte: Arquivo Google da Revista LIFE. Fotografia de Walter Sanders. Disponível em http:// images.google.com/hosted/life/a899fa27e5156c77.html, acessado em 4/1/2013.

58 CEDOC/UESC. Diário da Tarde, 25/6/1931. p. 4.

59 CEDOC/UESC. Diário da Tarde, 25/6/1931. p. 4. 
As medidas tomadas pela Sociedade dos Condutores de Carroça de Ilhéus causou reação imediata das casas exportadoras da cidade. No dia 29 de junho de 1931, a Associação Comercial de Ilhéus reuniu-se para tratar do ofício enviado pelos carroceiros determinando a regulamentação de suas atribuições profissionais. Os patrões decidiram oficiar aos trabalhadores dizendo não concordar com as iniciativas assumidas pela categoria, argumentando que viriam a trazer prejuízo para o comércio. Deliberaram também por procurar o prefeito municipal a fim de que fossem assegurados a ordem e o serviço de transporte do comércio. ${ }^{60}$ No ofício encaminhado para a Sociedade dos Condutores, diversas casas comerciais alegavam que "a despeito da simpatia que ora inspiram os condutores cujos direitos essa sociedade ampara, devemos dizer-lhes que não nos é dado concordar, no momento, com qualquer modificação que desejam fazer no serviço em foco". Os comerciantes solicitaram ainda que tais medidas pudessem ser transferidas para "melhor oportunidade; para quando a situação geral permitir; para quando a lavoura do cacau, mais bem recompensada puder arcar com mais a sobrecarga decorrente da resolução de que VV. Sa. nos dão aviso". ${ }^{61}$

Infelizmente, não sabemos se o prefeito Eusínio Lavigne tomou ciência das correspondências enviadas pela Associação Comercial de Ilhéus e pelas agremiações proletárias em questão. Apesar disso, o clima de tensão em torno de patrões e trabalhadores já pairava no ar na virada de junho para julho de 1931. O estopim foi a deflagração de greve dos empregados das docas e armazéns na manhã do dia $1^{\circ}$. A categoria exigiu que o salário de $6 \$ 000$ diários fosse elevado para $9 \$ 000$. Sabe-se que até às 9 horas da manhã os operários estiverem parados em frente aos primeiros armazéns, aguardando que a comissão formada para entendimento com os chefes do porto pudesse negociar. Depois da rodada de conversas, a Companhia Industrial de Ilhéus, que administrava as atividades portuárias, sinalizou que o aumento interessava aos seus diretores, mas que não poderia "resolver de pronto" a questão. Diante das intermediações para solucionar o caso, ficou estabelecido um reajuste provisório de $8 \$ 000$ diários, aceito pela categoria e determinando o final da parede. ${ }^{62}$

Dias depois foram os condutores de carroça que decidiram entrar em greve pacífica. $\mathrm{O}$ objetivo da paralisação das atividades foi exigir que as casas comerciais respeitassem as medidas tomadas pela sociedade dos carroceiros de não realizar a carga e a descarga dos produtos nos armazéns do porto. A Associação Comercial de Ilhéus formou nova comissão para se entender com o prefeito Lavigne, solicitando que ele intermediasse as negociações com os trabalhadores. Durante a reunião realizada entre prefeito, diretor do grêmio patronal e o presidente da associação em greve, alguns pontos essenciais foram solucionados, mas não o suficiente para terminar o movimento. No dia 6 de julho houve um conflito nas proximidades da Casa Wildberger \& Cia., quando os patrões acusaram os carroceiros de atitude hostil por ter impedido o carregamento de um caminhão a serviço da referida empresa. ${ }^{63}$ Depois disso, os policiais foram distribuídos em várias patrulhas no cais, com ordens para impedir qualquer excesso e garantir aos que não participavam da greve, o acesso ao trabalho normalmente ${ }^{64}$.

60 Arquivo da Associação Comercial de Ilhéus (ACIOS). Livro de atas da Assembleia Geral da Associação Comercial de llhéus (1928-1935). 29/6/1931. ff. 57-57v.

61 CEDOC/UESC. Diário da Tarde, 30/6/1931. p. 4.

62 CEDOC/UESC. Diário da Tarde, 1/7/1931. p. 1.

63 AACIOS. Livro de atas da Assembleia Geral da Associação Comercial de llhéus (1928-1935). 6/7/1931. ff. 57v-58v.

64 CEDOC/UESC. Diário da Tarde, 6/7/1931. p. 4. 
Outra importante informação que correu as ruas de Ilhéus foi a convocação de um assembleia geral para unificar a classe trabalhadora da cidade. A reunião ocorreria na sede da União Protetora dos Artistas e Operários no dia 8 de julho, às 20 horas. ${ }^{65} \mathrm{~A}$ intenção era congregar o contingente proletário do município para promover sua unificação e fortalecer as associações existentes. Diante deste quadro de mobilização, carroceiros em greve e encontro para promover a união dos trabalhadores, as autoridades ilheenses resolveram interceder. A notícia deu conta que tendo sido publicado um aviso de um encontro para "unificação das classes trabalhistas [...] a polícia que tem ordens severas para impedir reuniões cujos fins sejam por elas ignorados, procurou intervir no caso para conhecer dos propósitos da referida assembleia". O resultado disso foi o delegado tenente José Anselmo (o mesmo que esteve no comando do Tiro 500 no processo revolucionário e ficou conhecido pela violência nas abordagens) comparecer à sede da "Protetora" no dia 5 de julho onde encontrou as lideranças organizando as atividades da assembleia e determinou a prisão dos presidentes das sociedades que participaram das greves e dos líderes da paralisação. ${ }^{66}$

Os ânimos ficaram ainda mais acirrados. Os trabalhadores mantiveram a paralisação e demonstraram solidariedade com os presos. Entre eles estava Nelson Schaun. De acordo com a imprensa, os detidos foram postos em liberdade ao final do dia e, em seguida, após intermediações de agremiações trabalhistas que não participaram do movimento, puseram fim aos dias de greve. Após sair da prisão, Schaun enviou telegrama para o interventor federal Arthur Neiva e para o ministro da justiça Oswaldo Aranha, descrevendo as medidas policiais contra ele, conforme segue abaixo.

Peço licença [para] comunicar vossencia [os] motivos infundados [pelos quais] fui injustamente preso. Tenente José Anselmo que, levando malévolas intrigas, falsas informações, quis dar-me como chefe comunista. Professor [da] escola normal, vice-diretor [do] ginásio local, elemento [de] várias sociedades, membro [de] tradicional família [em] Ilhéus, sempre colocado frente [as] causas justas, dignas, bem coletivo, nem servia eu pudesse estar envolvido [em] movimento qualquer contra estabilidade [das] instituições, pois, para ser preso violentamente sem formalidades. Força pública, Tiro 500, Tiro Pirangy, requisitado [pelo] mesmo tenente, enchendo [a] cidade de maior pavor sobressalto, ameaçou textualmente eliminar minha própria vida. Apenas tenho procurado sindicalizar classes trabalhistas dentro [da] ordem, [da] lei, [de] acordo [ao] próprio ministério [do] trabalho. Peço garantias [de] providências [para] não ser vítima [de] futuros atentados. Nelson Schaun. ${ }^{67}$

Schaun procurou se desvencilhar da ideia de que era comunista e/ou que estava promovendo a instabilidade política em Ilhéus. Não se pode afirmar categoricamente, mas é provável que as autoridades o acusassem de querer desestabilizar o governo a partir da sua inserção nos meios trabalhistas. Deve-se levar em consideração que esta era uma gestão recente, de poucos meses e, portanto, ainda muito sensível às pressões sociais das agremiações laborais. Outra questão importante é que as tentativas de Lavigne de se aproximar do operariado e suas organizações não resistiram às greves por direitos e por melhores condições de

65 CEDOC/UESC. Diário da Tarde, 5/7/1931. p. 4.

66 CEDOC/UESC. Diário da Tarde, 7/7/1931. p. 1.

67 APEB. Telegrama de Nelson Schaun para o interventor federal Artur Neiva. 8/7/1931. ff. 1-2. Fundo: Secretaria de governo, cx. 1850. Doc. 2018. 
trabalho. Na prática, quando os grêmios ultrapassaram os limites da negociação, restou a prática de tratar a "questão social como uma questão de polícia". Isso indica que ao fazer a "Revolução" em nome da regeneração do país e das relações de trabalho, quando as condições de pressão eram alteradas, as autoridades de Vargas utilizaram a polícia para conter forças rebeldes. Como afirma John French, enquanto o governo proclamava leis, sua polícia continuou "metendo o pau" quando os trabalhadores travavam suas lutas. ${ }^{68}$ Talvez por isso, a Associação Comercial tenha demonstrado seus "efusivos agradecimentos pelas enérgicas providências [que] acaba [de] tomar [o] delegado [de] polícia Tenente José Anselmo, terminado [a] greve [dos] trabalhadores carroceiros, que tantas ameaças trazia [a] tranquilidade [da] nossa cidade". ${ }^{69}$

\section{Considerações Finais}

Que vem a ser essa pretensão, neste momento revolucionário, de organização da forma governativa nacional? Permitam-se indagar ainda de uma coisa: - As classes trabalhistas que se pretendem unificar já tem existência legal, isto é, já foram aprovados os seus estatutos e estão competentemente registrados? Seria útil saber quais os fins que tem em vista cada uma delas. Sabem por que? [...] Para que não se incumbam de encargos que devem ser dados ou cometidos aos governos. Os governos, depois da Revolução, não serão mais para prometerem somente; tem de cumprir tudo quanto lhes for ordenado pela comunhão das classes, não apenas as trabalhistas, mas todas aquelas que constituem o povo brasileiro. [...] Para que não pretendam ou não se arroguem no direito de resolver isoladamente assuntos que pertencem a mais de uma classe. As formas de ultimatum que em tais casos costumam tomar as resoluções isoladas tendem a gerar desconfianças, prevenções e até reações que prejudicam de qualquer sorte a harmonia social ou a aproximação entre os irmãos ou os filhos da mesma pátria, sejam quais foram as distâncias que os separam. ${ }^{70}$

Pouco mais de uma semana após as greves de carroceiros e de carregadores, e da tentativa de promover uma assembleia de unificação das classes trabalhistas, J. Araújo Góes lançou um boletim pelas ruas de Ilhéus tratando do movimento dos trabalhadores em torno de sua unificação e das relações com o governo revolucionário. Góes foi um dos membros da Aliança Liberal na cidade e cumpria importantes funções no Clube 3 de outubro, legião criada para dar suporte político e ideológico ao regime implantado. O boletim escrito trazia a preocupação com os percursos trilhados pelas organizações proletárias ilheenses no contexto de implantação da política revolucionária na cidade. É possível vislumbrar um modelo de corporativismo embrionário em que se prega a colaboração de classes com a intermediação do Estado e que ficará sistematizado no conjunto de leis trabalhistas que serão decretadas entre 1931 e 1934. Para o governo, controlar as atividades das associações de classe era uma forma de colocar sob sua esfera de influência uma cultura operária erguida ao longo da década de 1920 e que chegava ao

68 FRENCH. John. "Proclamando leis, metendo o pau e lutando por direitos". In: LARA, Silvia Hunold e MENDONÇA, Joseli Maria Nunes (orgs.). Direitos e justiças no Brasil. Campinas, SP: Editora da Unicamp, 2006.

69 APEB. Telegrama de Misael Tavares para o interventor Arthur Neiva. 8/7/1931. Fundo: Secretaria de governo, CX. 1850 , doc. 2018.

70 APEB. Ao povo - A constituição das classes e a pretendida unificação das classes trabalhistas em Ilhéus. 15/7/1931. f. 1. Fundo: Secretaria de governo, Cx, 1852, doc. 2022. 
decênio seguinte com expectativas de conquistas de direitos que melhorassem as condições de vida das diversas categorias. ${ }^{71}$

O quadro de instabilidade política que rondou a transição da primeira para a segunda República brasileira não pode ser pensado sem antes se entender o comportamento da classe trabalhadora nesse contexto. Em Ilhéus, apesar da fragilidade organizativa que as permeavam, as sociedades proletárias não apenas lutaram por sua própria sobrevivência enquanto organização, como também promoveram greves e campanhas por direitos e cidadania, e teceram relações políticas vitoriosas com os poderes públicos durante os anos 1920. Tais elementos possibilitaram que os trabalhadores fossem elevados à condição de relevante ator coletivo nos rumos das eleições e da revolução de 1930. Vimos que "conservadores/ legalistas" e "aliancistas" procuraram cativar as entidades para conquistar apoio e adeptos para os projetos políticos que desenharam para o Brasil. Isso mostra que é preciso ampliar o olhar da historiografia de "mundos do trabalho" para experiências operárias no universo da política republicana que extrapolem outras fronteiras brasileiras - no nosso caso, Ilhéus, sul da Bahia.

Estudar a movimentação dos trabalhadores diante do contexto de incertezas dos arredores de 1930 contribui também para discutir como a "questão social" foi abordada antes e depois da Revolução. Foi possível observar que as relações entre agremiações proletárias e as oligarquias ilheenses da Primeira República ocorriam no campo do paternalismo, em que coronéis e autoridades políticas se aproximavam das demandas das associações para conquistar a simpatia de caixeiros, artesões e operários. Notamos que às vésperas das eleições, as principais lideranças partidárias arregimentavam-se para assistir as iniciativas da cultura associativa dos trabalhadores: formatura de alunos, apresentações de filarmônicas e comemoração de datas magnas. Desta forma, as classes dominantes políticas preferiram, por vezes, a negociação e o diálogo com o contingente de empregados, ao invés de tratar a "questão social como uma questão de polícia", como frisava o velho aforisma.

Em contrapartida, vimos que o pós-Revolução ficou demarcado pelo uso da força policial para reprimir as manifestações e as greves elaboradas por carroceiros e carregadores. Apesar da tentativa de se aproximar dos grêmios proletários, Eusínio Lavigne viu-se forçado a desbaratar e prender lideranças da parede para conter os ânimos dos trabalhadores de Ilhéus. Nesse sentido, os esforços dos intelectuais e dos agentes políticos do governo em construir as bases do corporativismo trabalhista contrastaram com as tensões e as dificuldades de implantar a sindicalização no interior do mundo do trabalho, em especial de Ilhéus. Aliás, devemos considerar ainda que uma das principais lideranças do proletariado ilheense pertencia às facções oligárquicas da República decaída - Nelson Schaun - que se apropriava das causas da classe para se projetar política e socialmente, enquanto o governo municipal de Vargas usava da força para intervir entre os trabalhadores. Vê-se, assim, que as especificidades das experiências de organização operária em cada parte do País deslocam o posicionamento de sujeitos individuais e coletivos no cenário de incertezas antes e depois de 1930. Por sinal, as tensões do governo com o associativismo operário não acabariam com as mobilizações de julho de 1931, pois em novembro do mesmo ano um grupo de estivadores demonstrou insatisfação com a sindicalização da categoria nos termos da lei 19.770 , sendo preciso que

71 Sobre o sindicalismo corporativista, cf. ARAÚJO, Ângela Maria C. "Estado e trabalhadores". In: ARAÚJO, Ângela (org.). Do corporativismo ao neoliberalismo: Estado e trabalhadores no Brasil e na Inglaterra. São Paulo: Boitempo editorial, 2002. p. 36. 
o interventor Juracy Magalhães enviasse delegados da sucursal de Salvador para serenar os ânimos, e que o prefeito gastasse bastante tempo para solucionar o "caso dos estivadores", conforme destaca em cartas e telegramas. ${ }^{72}$

Sabemos que as relações entre trabalhadores e o mundo da política deram apenas um passo em direção à redefinição do papel que a classe trabalhadora passou a desempenhar a partir da década de 1930. Eram tempos de reconfiguração dos espaços institucionais dos operários, cujas tradições de solidariedade e organização advindos da República anterior, depararam-se com a intervenção cada vez mais frequente do Estado autoritário e centralizador de Vargas. Mas não foram somente os poderes constituídos que notaram o peso político que o operariado ganhou. Aliás, a história mostraria que ela não sairia mais de cena nos anos vindouros, sendo atrativa para partidos de direita e de esquerda, de oposição ou governista. Doravante, o que importa é o que os trabalhadores fizeram parte deste mundo da política, não cabendo apenas a ideia de que foram passivos, inertes ou massa de manobra nos destinos da República brasileira.

Recebido em 08/06/2013

Aprovado em 03/10/2013

72 APEB. Cartas e telegramas recebidos pela Interventoria. 24/11/1931 e 26/11/1931. Fundo: Secretaria de governo, Cx. 2019, doc. 2020. 